\title{
Changes in climate indices for Serbia according to the SRES-A1B and SRES-A2 scenarios
}

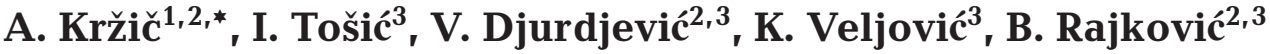 \\ ${ }^{1}$ Institute of Physics, Pregrevica 118, 11080 Belgrade, Serbia \\ ${ }^{2}$ Republic Hydrometeorological Service of Serbia, SEEVCCC, Kneza Viseslava 66, 11000 Belgrade, Serbia \\ ${ }^{3}$ University of Belgrade, Faculty of Physics, Dept. of Meteorology, Dobracina 16, 11000 Belgrade, Serbia
}

\begin{abstract}
Changes in 7 climate indices related to temperature or precipitation in Serbia were estimated for the reference period 1961-1990 and for the future period 2071-2100, as derived from the results of the coupled regional climate model EBU-POM. In order to verify the appropriateness of the EBU-POM to simulate regional climate in the future, changes in the indices of intensive events were studied on the basis of the model data and daily series of temperature and precipitation observations from 17 meteorological stations in Serbia for the reference period. The results show an overall increase in the surface air temperature of about 2 and $4{ }^{\circ} \mathrm{C}$ and a decrease in seasonal precipitation sums of about 13 and $6 \mathrm{~mm}$ for the A1B and A2 scenarios, respectively. It is likely that the number of days with absolute maximum temperature $>30^{\circ} \mathrm{C}$ (tropical days) will increase, while the total number of days with absolute minimum temperature $<0^{\circ} \mathrm{C}$ (frost days) will decrease in the future. A shorter duration of the frost period and a longer duration of dry and vegetation periods over the Serbian region is expected.
\end{abstract}

KEY WORDS: Climate indices $\cdot$ Regional climate model $\cdot$ A1B scenario $\cdot$ A2 scenario $\cdot$ Serbia

\section{INTRODUCTION}

Changes in severe weather and climate events are among the most serious challenges to society in coping with a changing climate. The sustainability of economic development and living conditions depends on our ability to manage risks associated with extreme events. Although severe weather is not always directly related to environmental disasters (damaging impacts can also occur in the absence of a very rare or intense climatic event), a systematic change in severe weather will also very likely be accompanied by a systematic change in hazardous weather conditions that have adverse effects on ecosystems or sectors of society (human safety and health, water management, agriculture, energy, insurance, tourism, transport).

There are several indications attributable to the large climate changes due to the increase in green- house gases (GHG; IPCC 2007). The only way to simulate future climate is by using global oceanatmosphere coupled models. To provide information about fine-scale regional climate, the best approach is dynamic downscaling, since regional models offer higher spatial resolution due to more precise descriptions of regional terrain and surface characteristics (Giorgi \& Mearns 1999). A number of regional climate model systems have been developed during the last 2 decades. From such models more reliable analyses, impact assessment, and adaptation studies are possible. We are interested in the results over the Mediterranean region (e.g. Giorgi 2006, Somot et al. 2008, Artale et al. 2010), in particular over the area of southeastern Europe (Bartholy \& Pongrácz 2007). For the eastern Mediterranean (EM), the research on precipitation is more complicated than in other Mediterranean areas, due to complex topographical features and sparse station data. 
The changes in climate extremes in the Mediterranean basin are seen in the increase in heavy precipitation and rise in extreme temperatures (Goubanova \& Li 2007). Recently, Gao \& Giorgi (2008) showed a widespread decrease in winter precipitation over most of the EM and warming during summer over the Balkans and western Turkey (5-6 ${ }^{\circ}$ ) for future climate conditions (2071-2100) under the emission scenarios A2 and B2. Önol \& Semazzi (2009), using the ICTP-RegCM3, investigated the role of global warming in modulating the future climate for the time frame 2071-2100 based on the A2 scenario over the EM. The major results were that, during summer, temperatures will increase by about $7^{\circ} \mathrm{C}$ over the Balkan countries (including Serbia), while changes for the rest of the region will be within the range of $3-4^{\circ} \mathrm{C}$.

To analyze events far from the mean climate range, but more likely to occur than outlying extremes, various precipitation and temperature indices have been introduced. They have been used to evaluate the present climate, starting with the work of Karl et al. (1996). Such work has been continued by, e.g., Frich et al. (2002) and Alexander et al. (2006). Klein Tank \& Können (2003), Kostopoulou \& Jones (2005), and Moberg et al. (2006) have focused on regional climate changes for the present climate. But climate indices can also be very helpful in indicating the consequences of various scenarios of climate change. Meehl et al. (2004), analyzing global simulations of the NCAR/Energy Parallel Climate Model for the climate of the 20th and 21st centuries found a general decrease in the number of frost days. Oikonomou et al. (2008) found longer dry spells, with reduced rainfall intensity over the EM for the future period 20702100, using results of the regional model HadRM3, for the B2 scenario.

In the present study, potential changes of climate indices over the Serbian region were considered. Serbia is located in the western Balkans, covering roughly the area $42-46^{\circ} \mathrm{N}$ and $19-23^{\circ} \mathrm{E}$. Recent studies of the Serbian region (e.g. Unkasevic et al. 2005) have shown that an increasing tendency exists in the observed extreme winter and summer temperatures, with more warming in the absolute minimum temperatures (especially during winter) than in the absolute maximum temperatures.

The purpose of the present study is to reformulate standard results from climate simulations, namely long-term and large-area averages to a more detailed and easier to interpret form of climate indices. From the previous work of other authors (e.g. Önol \& Semazzi 2009), we know that the Balkans will be under significant stress, but we examine the relevance of regional simulations for a sub-region of Serbia. This should be possible to achieve through the comparison of results from simulations and in situ (station) measurements.

Indices are calculated for the end of the 20th and 21 st centuries according to A1B and the A2 scenarios (Nakicenovic \& Swart 2000), which are known as 'medium' and 'high' forcing scenarios. Atmospheric $\mathrm{CO}_{2}$ concentration is close to $690 \mathrm{ppm}$ for the A1B and to $850 \mathrm{ppm}$ for the A2 scenario at the end of the 21st century, which is about 1.8 and 2.2 times higher than the present value of $\sim 390 \mathrm{ppm}$.

The paper is organized as follows. The models, data, and indices used are presented in Section 2. Verification of the EBU-POM Model is carried out in Section 3, in which indices and their future changes are also presented. A discussion and conclusions are given in Section 4.

\section{METHODS}

Global ocean-atmosphere coupled models are certainly the best tools that we have to make future climate scenario projections. Due to their coarse spatial resolution, they can hardly be used in impact-oriented studies, for which a downscaling procedure is necessary. A commonly used downscaling approach is a high-resolution limited-area model nested in the global model. This approach allows many detailed physical parameterizations in regional climate models (RCM) to simulate local weather and climate events.

\subsection{The global model}

The global modeling data employed in the present study are time series obtained from climate simulations carried out with the SINTEX-G (SXG) coupled atmosphere-ocean general circulation model (AOGCM), which is an evolution of the SINTEX and SINTEX-F models (Gualdi et al. 2003a,b, Guilyardi et al. 2003). The ocean model component is the reference Version 8.2 of the Ocean Parallelise (OPA; Madec et al. 1998). To avoid singularity at the North Pole, it has been transferred to 2 poles located in Asia and North America. The model longitude-latitude resolution is $2 \times 2^{\circ}$ cosine (latitude) with increased meridional resolution to $0.5^{\circ}$ near the equator. The model has 31 vertical levels, 10 of which lie in the upper $100 \mathrm{~m}$ of the ocean. For details see Madec et al. (1998) or www.lodyc.jussieu.fr/opa/. 
The evolution of sea ice is described by the Louvain-La-Neuve Sea Ice Model (LIM; Fichefet \& Morales Maqueda 1997). The atmospheric model component is the latest version of ECHAM-4 (Roeckner et al. 1996). The horizontal resolution was T106, corresponding to a Gaussian grid of about $1.125 \times$ $1.125^{\circ}$. A hybrid sigma-pressure vertical coordinate is used with 19 vertical levels. A detailed discussion can be found in Roeckner et al. (1996).

The SXG Model has been adopted for climate change runs for the time period 1870-2000, based on the 20C3M experiment (Climate of the 20th Century), and for the time period 2001-2100 based on 2 climate scenarios (A1B and A2).

\subsection{The regional model}

The EBU-POM is a 2-way coupled RCM, with the Eta/NCEP-Limited Area Model as its atmospheric part and the Princeton Ocean Model (POM) as its oceanic part. The atmospheric component has been nested within a global model for the purpose of seasonal predictions (Fennessy \& Shukla 2000). It has also been used in the downscaling assessment over the United States (Xue et al. 2007). The Eta/NCEP is defined on the E-grid according to the nomenclature of Arakawa and Wininghoff (Winninghoff 1968, Arakawa \& Lamb 1977), with the Eta vertical coordinate (Mesinger et al. 1988). Its dynamic core has efficient time-stepping and comprehensive physics (Janjic 1990, 1996). The original radiation scheme (GFDL radiation scheme; Fels \& Schwarzkopf 1975) was replaced with a scheme implemented by Pérez et al. (2006), which enabled changes of GHG concentrations during the experiment. As in the global model, concentrations of GHGs were changed following the A1B and A2 scenarios. Tabular data on GHG concentrations were taken from the GISS climate model page (http://data.giss.nasa.gov/ modelforce/ghgases/). The center of the atmospheric model is at $42.5^{\circ} \mathrm{N}, 16^{\circ} \mathrm{E}$. In a vertical direction, the model has 32 levels, with the first level at $20 \mathrm{~m}$ and the top level at $10 \mathrm{hPa}$. The atmospheric part of the EBU-POM was initialized and forced by lateral boundary conditions using fields from the SXG.

The ocean component is the POM, a 3-dimensional, primitive equation, numerical model developed by Blumberg \& Mellor (1987). A comprehensive description is in Mellor (2002). Several groups have demonstrated the capability of POM to simulate Mediterranean oceanic circulation (e.g. Zavatarielli \& Mellor 1995, Drakopoulos \& Lascaratos 1999).
An important part of every coupled model is the method of data exchange between its 2 components. Due to the very different geometries of the 2 model components, special attention was paid to the design of this coupling module (Djurdjevic \& Rajkovic 2008). Exchanges of atmosphere fluxes and sea surface temperature (SST) between the 2 components were carried out interactively, during integration, using specially designed coupler software. During every physical time step of the atmospheric model (360 s), sensible and latent heat, momentum, short- and long-wave- and precipitation-evaporation fluxes, needed for ocean forcing, were transferred to the ocean model grid. Subsequently, SST was transferred back onto the atmosphere model grid, serving as the new bottom boundary condition. Coupling between the atmosphere and ocean was only over the Mediterranean, with initialization as in Brasseur et al. (1996). Over the Atlantic and Black Sea, the bottom boundary condition (SST) was derived from the SXG integration.

The atmospheric model domain covers almost the entire European region (Fig. 1), with a horizontal resolution of $0.25^{\circ}$. The horizontal resolution of the ocean model was $0.2^{\circ}$. Regional integrations were performed as $30 \mathrm{yr}$ time slices of global model experiments for 2 periods: 1961-1990 and 2071-2100.

\subsection{Data}

The simulated climate of the European region and the main features of its variability were evaluated by comparing the model results with observational data sets. We used data from the NCEP re-analysis (Kalnay et al. 1996) and the observed precipitation and air surface temperature from the Climate Research Unit (CRU) data set (Jones et al. 2006). Perhaps the biggest advantage in dynamic downscaling is in the convective precipitation simulated. This is most notable in the case of orographic precipitation, which is characteristic for the SE Adriatic coast and well produced in the regional runs (Gualdi et al. 2008)

The climate in Serbia is continental. The mountain ranges around and in Serbia and the Mediterranean Sea influence above all the climatic conditions of the region, leading to a high spatial variability. Mean annual temperatures are about $11^{\circ} \mathrm{C}$ in the plains, with altitudes of up to $300 \mathrm{~m}$ (North Serbia), and about $10^{\circ} \mathrm{C}$ for regions with altitudes between 300 and $500 \mathrm{~m}$. For mountainous regions in the south, the mean annual temperature is about $6^{\circ} \mathrm{C}$, decreasing to 


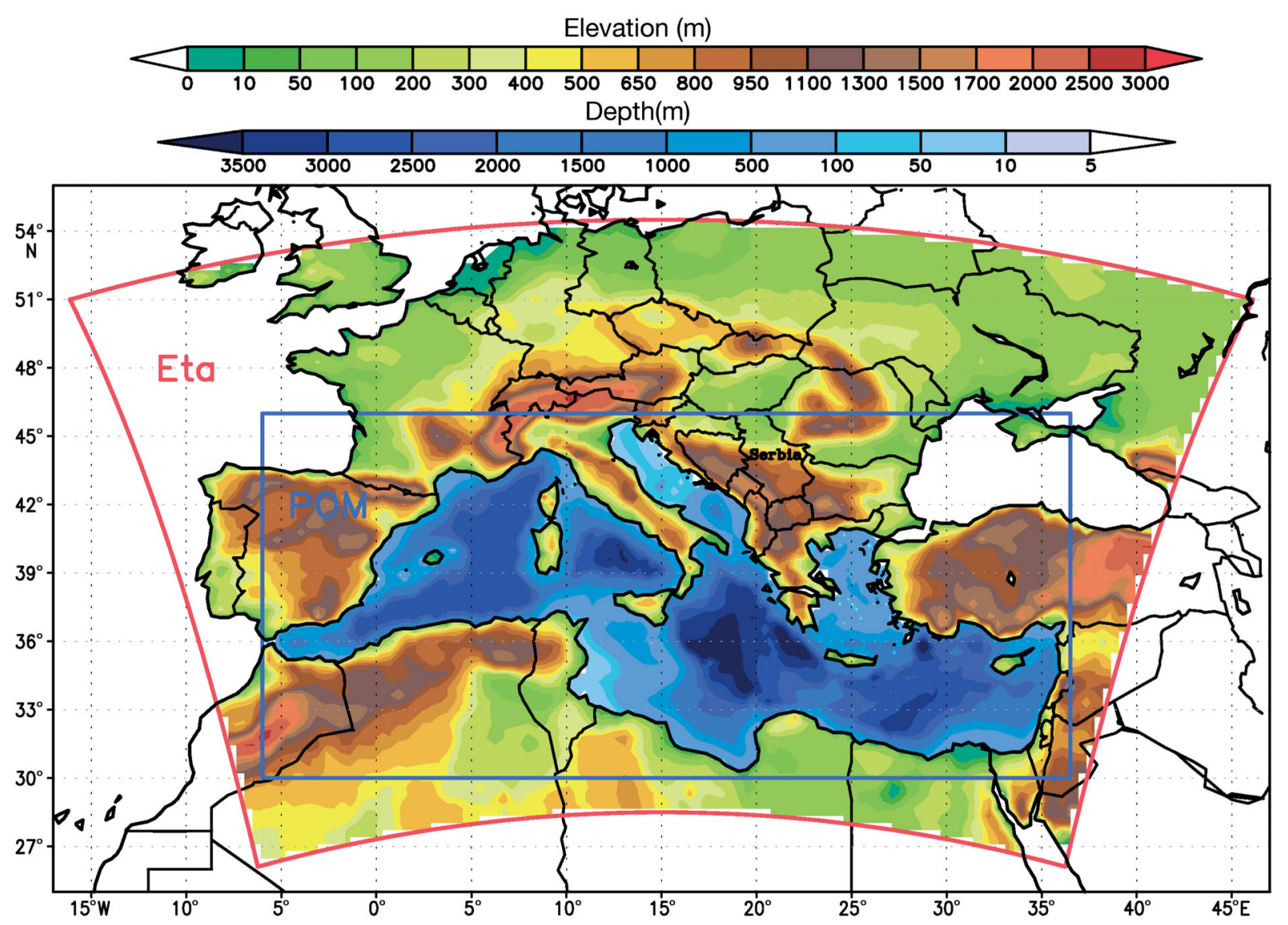

Fig. 1. Model domains. Area bounded by outer line is the Eta Model domain; the inner rectangle represents the domain boundary of the Princeton Ocean Model (POM)

$3^{\circ} \mathrm{C}$ at altitudes over $1500 \mathrm{~m}$. Maximum precipitation occurs in June, and minimum in February. The annual precipitation totals contrast notably from north to south, with $600 \mathrm{~mm} \mathrm{yr}^{-1}$ over northern Serbia. The mountain region in the south of Serbia receives around $1000 \mathrm{~mm} \mathrm{yr}^{-1}$, while some peaks receive $>1500 \mathrm{~mm} \mathrm{yr}^{-1}$. Daily precipitation and temperature time series from 17 meteorological stations evenly distributed throughout the study region, for the period 1961-1990, were employed for the calculation of indices for the region of Serbia. All data series were complete, without missing values. Technical and quality controls for these measurements were made by the National Meteorological Service of Serbia.

To better describe the spatial features of the estimated changes, the region was divided into 2 subregions called North Serbia (NS) and South Serbia (SS), due to the fact that mountains dominate in the south, whereas lowland is found in the north (to the north of the Sava and Danube Rivers). Also, regional averaging may reduce or eliminate the effects of possible inhomogeneities in the underlying series.

\subsection{Indices}

In order to objectively study recent climate change, particularly change in the frequency of extreme precipitation and temperature events, climate indices can be used (Frich et al. 2002, Bartholy \& Pongrácz 2007). Climate indices condense relatively complex data into understandable information that can be used by a wide range of (end) users. Such indices are recommended by the joint Working Group on Climate Change Detection of the World Meteorological Organization-Commission for Climatology (WMOCCL) and the research program on Climate Variability and Predictability (CLIVAR), as well as by European research project STARDEX (Peterson et al. 2001).

The indices we used in the present study were selected to examine changes in the severity of weather conditions over Serbia under the A1B and A2 scenarios (shown in Table 1; Alexander et al. 2006). The indices were calculated for the present period (1961-1990) and a future period (2071-2100) for all seasons, for both stations and grid points aver- 
Table 1. Extreme temperature and precipitation indices

\begin{tabular}{|c|c|c|}
\hline Indicator & Abbreviation & Definition \\
\hline \multicolumn{3}{|l|}{ Based on temperature } \\
\hline Total number of tropical days & $\mathrm{Td}$ & Number of days with absolute maximum temperature $>30^{\circ} \mathrm{C}$ \\
\hline Total number of frost days & $\mathrm{Fd}$ & Number of days with absolute minimum temperature $<0^{\circ} \mathrm{C}$ \\
\hline Maximum number of consecutive frost days & CFD & $\begin{array}{l}\text { Maximum number of consecutive days with absolute minimum } \\
\text { temperature }<0^{\circ} \mathrm{C}\end{array}$ \\
\hline Growing season length (d) & GSL & $\begin{array}{l}\text { Number of days between the first occurrence of at least } 6 \\
\text { consecutive days with daily mean temperature }>5^{\circ} \mathrm{C} \\
\text { (beginning) and the first occurrence after } 1 \text { July of at least } 6 \\
\text { consecutive days with daily mean temperature }<5^{\circ} \mathrm{C} \text { (ending) }\end{array}$ \\
\hline \multicolumn{3}{|l|}{ Based on precipitation } \\
\hline Heavy precipitation days & $\mathrm{R} 10$ & Number of days with precipitation $\geq 10 \mathrm{~mm} \mathrm{~d}^{-1}$ \\
\hline Maximum number of consecutive dry days & CDD & $\begin{array}{l}\text { Maximum number of consecutive days with daily precipitation } \\
<1 \mathrm{~mm}\end{array}$ \\
\hline Simple daily intensity index $\left(\mathrm{mm} \mathrm{d}^{-1}\right)$ & SDII & Period total/no. of days with precipitation $\geq 1 \mathrm{~mm}$ \\
\hline
\end{tabular}

aged over 2 sub-regions of the country. Also, the seasonal differences between future averages and the corresponding present values of indices were calculated, as well as the difference between indices based on simulated and observed data. The Kendall test was used to estimate the statistical significance of index trends.

Most indices used are threshold indices; they are not meaningful for all climates (Alexander et al. 2006), but they can provide insights into extra-tropical (mid- to high-latitude) regions (Tebaldi et al. 2006). In addition, changes in these indices may have profound impacts on particular sectors of society or ecosystems:

- The study of tropical days (Td) is of interest for the description of a region's climate, because very hot days are of great importance, not only for bioclimatology and applied sciences, but also for individuals who are sensitive to heat stress (Nastos \& Matzarakis 2008).

- Frost days and consecutive frost days (Fd and CFD), measuring frost in the air and the duration of frost periods, indicate the beginning and the end of the cold season.

- The maximum number of consecutive dry days (CDD) is a drought indicator (Frich et al. 2002).

- Heavy precipitation days (R10) are directly related to extreme precipitation events, while the simple daily intensity index (SDII) is defined to examine the tendencies in precipitation events (Kostopoulou \& Jones 2005).

- The length of the growing season (GSL) can indicate spring and autumn anomalies (Frich et al. 2002). GSL is a simple measure of the difference between the end and the beginning of the growing season. The beginning/end is given as the average number of days from the beginning of the year when the growing season starts/ends.

\section{RESULTS}

\subsection{Simulation}

The first step in assessing a climate model is to compare its simulations with observed climatology. Verification of EBU-POM for the European region is done using CRU data (Djurdjevic \& Rajkovic 2011). The annual bias over land for the whole model domain is $0.64^{\circ} \mathrm{C}$ per $2 \mathrm{~m}$ for temperature and -0.67 $\mathrm{mm} \mathrm{d}^{-1}$ for precipitation; see e.g. Jacob et al. (2007), where 10 RCMs were verified against CRU and reanalysis data.

Next, we present a detailed analysis of the EBUPOM results for Serbia. Model results were verified against observations from 17 stations. The seasonal averages of the mean, minimum, and maximum temperatures for the reference period 1961-1990 and 2 future scenarios are presented in Tables $2 \& 3$. As a measure of temperature interannual variability we used the interannual standard deviation of seasonal temperatures calculated over $30 \mathrm{yr}$ of observations and simulations. The coefficient of variation was adopted as a measure of precipitation variability in order to remove the dependency of the standard deviation on mean values (e.g. Giorgi et al. 2004a).

The largest difference in the mean temperature between models and observations is during the summer in the north $\left(\sim 6^{\circ} \mathrm{C}\right.$ for EBU-POM and $\sim 3^{\circ} \mathrm{C}$ for SXG), while the smallest is for autumn $\left(\sim 1^{\circ} \mathrm{C}\right)$ and is quite homogenous in space (Table 2). This temperature difference over NS is mainly caused by error in 
Table 2. Seasonal $T_{\text {mean }}$ (mean temperature, $\pm \mathrm{SD}$ ) for North and South Serbia over the reference period and for the A1B and A2 scenarios (2071-2100). Obs: station observations; E-P: EBU-POM model; SXG: SXG model; seasons given according to months

\begin{tabular}{|c|c|c|c|c|c|c|c|c|}
\hline & \multirow[t]{3}{*}{ Season } & \multirow{2}{*}{\multicolumn{3}{|c|}{$-1961-1990$}} & \multicolumn{4}{|c|}{$-2071-2100$} \\
\hline & & & & & & & & 2 \\
\hline & & Obs & E-P & SXG & E-P & SXG & E-P & SXG \\
\hline \multirow[t]{4}{*}{ North } & MAM & $11.2 \pm 1.1$ & $13.0 \pm 0.9$ & $10.8 \pm 1.2$ & $15.4 \pm 1.1$ & $13.7 \pm 1.3$ & $16.6 \pm 1.2$ & $14.2 \pm 1.4$ \\
\hline & JJA & $20.3 \pm 0.7$ & $26.1 \pm 0.9$ & $23.7 \pm 1.4$ & $29.6 \pm 0.9$ & $28.9 \pm 1.6$ & $30.9 \pm 1.4$ & $29.7 \pm 2.0$ \\
\hline & $\mathrm{SON}$ & $11.1 \pm 1.1$ & $12.5 \pm 1.0$ & $12.5 \pm 1.2$ & $14.5 \pm 0.9$ & $16.0 \pm 1.1$ & $15.2 \pm 1.0$ & $16.8 \pm 1.1$ \\
\hline & DJF & $0.2 \pm 2.0$ & $2.6 \pm 1.2$ & $2.1 \pm 1.3$ & $4.7 \pm 1.1$ & $4.8 \pm 1.0$ & $5.6 \pm 0.8$ & $5.6 \pm 1.1$ \\
\hline \multirow[t]{4}{*}{ South } & MAM & $10.6 \pm 1.0$ & $10.0 \pm 0.9$ & $8.5 \pm 1.1$ & $12.6 \pm 1.0$ & $11.2 \pm 1.3$ & $13.7 \pm 1.1$ & $11.8 \pm 1.2$ \\
\hline & JJA & $19.5 \pm 0.8$ & $22.0 \pm 0.7$ & $22.1 \pm 1.3$ & $25.5 \pm 0.8$ & $27.0 \pm 1.4$ & $26.8 \pm 1.3$ & $27.7 \pm 1.7$ \\
\hline & SON & $10.8 \pm 1.1$ & $9.9 \pm 1.0$ & $11.0 \pm 1.0$ & $11.9 \pm 0.8$ & $13.8 \pm 1.0$ & $12.7 \pm 1.0$ & $14.8 \pm 1.1$ \\
\hline & DJF & $0.4 \pm 1.5$ & $0.6 \pm 1.0$ & $0.8 \pm 1.0$ & $2.8 \pm 1.0$ & $2.8 \pm 1.0$ & $3.8 \pm 0.9$ & $3.7 \pm 1.0$ \\
\hline
\end{tabular}

Table 3. Seasonal $T_{\min }$ and $T_{\max }$ (minimum and maximum temperature, $\pm \mathrm{SD}$ ) for North and South Serbia over the reference period and for the A1B and A2 scenarios (2071-2100). Abbreviations, see Table 2

\begin{tabular}{|c|c|c|c|c|c|c|c|c|c|}
\hline & \multirow{3}{*}{ Season } & \multicolumn{4}{|c|}{$-T_{\min }\left({ }^{\circ} \mathrm{C}\right)$} & \multicolumn{4}{|c|}{$-T_{\max }\left({ }^{\circ} \mathrm{C}\right)$} \\
\hline & & \multicolumn{2}{|c|}{ 1961-1990 } & \multicolumn{2}{|c|}{$2071-2100$} & \multicolumn{2}{|c|}{$1961-1990$} & \multicolumn{2}{|c|}{$2071-2100$} \\
\hline & & Obs & E-P & $\mathrm{A} 1 \mathrm{~B}$ & $\mathrm{~A} 2$ & Obs & E-P & $\mathrm{A} 1 \mathrm{~B}$ & A2 \\
\hline \multirow[t]{4}{*}{ North } & MAM & $5.8 \pm 1.5$ & $10.0 \pm 1.2$ & $12.3 \pm 1.5$ & $13.4 \pm 1.7$ & $16.8 \pm 0.9$ & $16.8 \pm 0.9$ & $19.5 \pm 0.9$ & $20.8 \pm 1.0$ \\
\hline & JJA & $14.1 \pm 0.8$ & $22.0 \pm 1.1$ & $25.4 \pm 1.1$ & $26.6 \pm 1.7$ & $26.4 \pm 0.6$ & $31.5 \pm 0.8$ & $35.3 \pm 0.7$ & $36.7 \pm 1.2$ \\
\hline & $\mathrm{SON}$ & $6.2 \pm 1.4$ & $9.2 \pm 1.1$ & $11.1 \pm 1.2$ & $11.9 \pm 1.1$ & $17.0 \pm 1.1$ & $16.9 \pm 1.2$ & $19.1 \pm 0.9$ & $19.8 \pm 1.1$ \\
\hline & DJF & $-3.1 \pm 2.3$ & $0.7 \pm 1.2$ & $2.6 \pm 1.2$ & $3.7 \pm 1.0$ & $3.7 \pm 2.1$ & $4.9 \pm 1.2$ & $7.3 \pm 1.1$ & $7.9 \pm 0.8$ \\
\hline \multirow[t]{4}{*}{ South } & MAM & $5.1 \pm 1.5$ & $6.9 \pm 1.1$ & $9.3 \pm 1.3$ & $10.4 \pm 1.4$ & $16.5 \pm 0.8$ & $14.3 \pm 0.9$ & $17.1 \pm 0.9$ & $18.5 \pm 0.9$ \\
\hline & JJA & $13.2 \pm 1.0$ & $18.3 \pm 1.0$ & $21.6 \pm 1.0$ & $22.9 \pm 1.6$ & $26.2 \pm 0.6$ & $27.2 \pm 0.7$ & $31.0 \pm 0.7$ & $32.3 \pm 1.1$ \\
\hline & $\mathrm{SON}$ & $5.9 \pm 1.4$ & $6.9 \pm 1.0$ & $8.9 \pm 1.0$ & $9.8 \pm 1.1$ & $17.2 \pm 1.1$ & $14.4 \pm 1.0$ & $16.7 \pm 0.8$ & $17.4 \pm 0.9$ \\
\hline & DJF & $-3.1 \pm 1.7$ & $-1.6 \pm 1.1$ & $0.5 \pm 1.2$ & $1.6 \pm 1.0$ & $4.3 \pm 1.6$ & $3.6 \pm 1.1$ & $6.0 \pm 0.9$ & $6.9 \pm 0.8$ \\
\hline
\end{tabular}

the minimum temperature, a quite common problem for climate models for the region of Pannonia known as the 'summer drying problem'. Hagemann et al. (2004) suggested that the problem is to be found in the soil type. Our sensitivity tests using different soil types were not able to explain the problem; a combination of surface parameterizations and larger scale dynamics is probably involved. The best agreement between maximum temperatures is in the spring and autumn in NS (Table 3). Önol \& Semazzi (2009) reported, for the Serbian region, a difference between their model values and observations of $2.4^{\circ} \mathrm{C}$ in the summer and $-0.6^{\circ} \mathrm{C}$ in autumn. There is also disagreement between our and their observations, probably stemming from the different sources of data used. The observed standard deviation for temperature, and thus the interannual variability, is maximal in winter $\left(1.5-2.3^{\circ} \mathrm{C}\right)$. In the other seasons, the observed standard deviation is more homogenous and varies in the narrower ranges of $0.7-1.1^{\circ} \mathrm{C}$ for mean temperatures (Table 2) and of $0.6-1.5^{\circ} \mathrm{C}$ for minimum and maximum temperatures (Table 3). Compared to observations, EBU-POM tends to underestimate interannual temperature variability, except in summer (Tables 2 \& 3), while SXG overestimates it, except in winter (Table 2).

In the future, the maximum increase of mean $\left(\sim 4.8^{\circ} \mathrm{C}\right.$ for EBU-POM and $\sim 6^{\circ} \mathrm{C}$ for $\mathrm{SXG}$; Table 2$)$ and maximum $\left(\sim 5.1^{\circ} \mathrm{C}\right.$; Table 3$)$ temperatures is expected for all of Serbia during the summer, according to the A2 scenario. For the other seasons, an increase within the range of $2-3^{\circ} \mathrm{C}$ is expected. Önol \& Semazzi (2009) pointed out that the largest increase would also be in summer, and would be slightly larger $\left(6.6^{\circ} \mathrm{C}\right)$ for the $\mathrm{A} 2$ scenario. The temperature variability generally increases in all seasons (with a maximum in summer), except in winter, for both scenarios and models (Tables $2 \& 3$ ).

Simulated and observed seasonal sums of precipitation are presented in Table 4. EBU-POM estimates a smaller amount of precipitation than is observed, except for winter in NS. Of all seasons winter precipitation is the best reproduced. EBU-POM tends to calculate less precipitation than SXG (except for summer in SS). In the simulations by Önol \& Semazzi (2009), the summer season is also drier than in the 
Table 4. Seasonal precipitation sums $( \pm \mathrm{CV})$ for North and South Serbia over the reference period and for the A1B and A2 scenarios (2071-2100). Abbreviations, see Table 2

\begin{tabular}{|c|c|c|c|c|c|c|c|c|}
\hline & \multirow{3}{*}{ Season } & \multicolumn{3}{|c|}{$-1961-1990 \longrightarrow$} & \multirow{2}{*}{\multicolumn{2}{|c|}{ A1B }} & \multicolumn{2}{|l|}{100} \\
\hline & & & & & & & A & \\
\hline & & Obs & E-P & SXG & E-P & SXG & E-P & SXG \\
\hline \multirow[t]{4}{*}{ North } & MAM & $138.4 \pm 0.27$ & $94.8 \pm 0.27$ & $149.8 \pm 0.29$ & $96.8 \pm 0.35$ & $135.9 \pm 0.20$ & $88.5 \pm 0.45$ & $141.0 \pm 0.37$ \\
\hline & JJA & $188.2 \pm 0.28$ & $60.5 \pm 0.39$ & $123.8 \pm 0.36$ & $50.2 \pm 0.37$ & $86.5 \pm 0.46$ & $51.4 \pm 0.38$ & $74.7 \pm 0.49$ \\
\hline & $\mathrm{SON}$ & $116.4 \pm 0.30$ & $78.0 \pm 0.49$ & $134.1 \pm 0.36$ & $63.8 \pm 0.49$ & $116.2 \pm 0.41$ & $77.7 \pm 0.45$ & $119.7 \pm 0.36$ \\
\hline & DJF & $113.9 \pm 0.41$ & $135.4 \pm 0.23$ & $144.2 \pm 0.21$ & $114.9 \pm 0.35$ & $135.0 \pm 0.36$ & $149.2 \pm 0.33$ & $163.9 \pm 0.28$ \\
\hline \multirow[t]{4}{*}{ South } & MAM & $181.1 \pm 0.25$ & $148.7 \pm 0.25$ & $174.3 \pm 0.30$ & $134.9 \pm 0.33$ & $154.7 \pm 0.30$ & $124.3 \pm 0.39$ & $131.9 \pm 0.38$ \\
\hline & JJA & $198.5 \pm 0.30$ & $121.9 \pm 0.41$ & $91.1 \pm 0.43$ & $104.8 \pm 0.36$ & $68.7 \pm 0.55$ & $113.7 \pm 0.37$ & $58.2 \pm 0.47$ \\
\hline & $\mathrm{SON}$ & $154.8 \pm 0.34$ & $89.4 \pm 0.44$ & $181.7 \pm 0.30$ & $78.5 \pm 0.44$ & $149.1 \pm 0.38$ & $79.2 \pm 0.36$ & $126.4 \pm 0.33$ \\
\hline & DJF & $146.1 \pm 0.31$ & $125.8 \pm 0.25$ & $221.0 \pm 0.22$ & $107.6 \pm 0.39$ & $185.5 \pm 0.32$ & $125.5 \pm 0.26$ & $192.4 \pm 0.27$ \\
\hline
\end{tabular}

observations, with a positive precipitation bias during winter and spring for the Balkans. The observed coefficient of variation (Table 4) shows a relatively uniform distribution, with values mostly between 0.25 (spring) and 0.41 (winter). The interannual variability in precipitation does not show pronounced seasonal variations. Both models show generally good agreement with observations, with a small underestimation in winter. In autumn, EBU-POM has a greater coefficient of variation than do SXG and observations.

Coming to simulation for the A2 scenario, the precipitation deficit is up to $24 \mathrm{~mm}(16.4 \%)$ in spring for $\mathrm{SS}$, except in the winter for NS, which shows an increase of $13 \mathrm{~mm}(9.6 \%)$. According to the A1B scenario, precipitation will decrease between 10 and 20 $\mathrm{mm}(9-18 \%)$, except for spring in the north with an increase of $2 \mathrm{~mm}(2.1 \%)$. SXG also shows a general decrease in precipitation, with the largest reduction of $55.3 \mathrm{~mm}$ during summer, based on the A2 scenario. Interannual variability is expected to be most pronounced in autumn according EBU-POM and in summer according to SXG, as it was in the reference period (Table 4). Throughout the Balkan countries, including Serbia, the summer season is dominated by drier conditions (40-60\% reduction; Önol \& Semazzi 2009).

The verification was also made in terms of relative frequencies of temperature and precipitation. The relative frequencies of seasonal temperature for NS and SS are shown in Fig. 2 for present and future periods. Good agreement between simulated and observed frequencies of temperature exists for all seasons, except for summer. In comparison with the present climate, means are expected to increase for all seasons in the future. Relative frequencies of monthly precipitation sums for the reference period (observations and EBU-POM results) and both scenarios are shown in Fig. 3. For NS, the largest differ- ences are for the lowest amounts of precipitation. For SS, the model overestimates precipitation sums of $<60 \mathrm{~mm} \mathrm{mo}{ }^{-1}$, but underestimates larger precipitation sums. As is common in many simulations, the weakest precipitation is overestimated (Dettinger et al. 2004). It seems that the best agreement is for the most frequent precipitation sums $\left(\sim 40 \mathrm{~mm} \mathrm{mo}^{-1}\right.$ in NS and $\sim 55 \mathrm{~mm} \mathrm{mo}^{-1}$ in SS). In the future, a small increase in the minimum monthly precipitation sums $\left(\leq 20 \mathrm{~mm} \mathrm{mo}^{-1}\right)$ is expected. In both regions, both distributions (A1B and A2 scenarios) are quite close to each other.

\subsection{Climate indices}

\subsubsection{Reference period (1961-1990)}

Seasonal averages of the indices for observations and EBU-POM, as well as seasonal differences between indices during the reference period 19611990 for NS and SS are presented in Table 5. The model overestimates the total number of tropical days (Td) in NS; overestimation is greatest in summer. This is not surprising bearing in mind the large positive bias in the model for $T_{\max }$ (Table 3 ). In SS, the overestimation of $\mathrm{Td}$ is smaller. During spring and autumn in SS, the model underestimates Td. Trends are negative for spring throughout Serbia, but are significant (at the $5 \%$ level) for observations in NS and for model results in SS. Nastos \& Matzarakis (2008) found a negative trend in the annual Td values in the period 1955-1976 and a positive trend between 1976 and 2000, in Greece.

The model underestimates the number of frost days (Fd) in both areas of Serbia and in all seasons, with more frost days in SS than in NS, especially in the winter. Apart from $\mathrm{Td}$ and $\mathrm{Fd}$, taking the fre- 

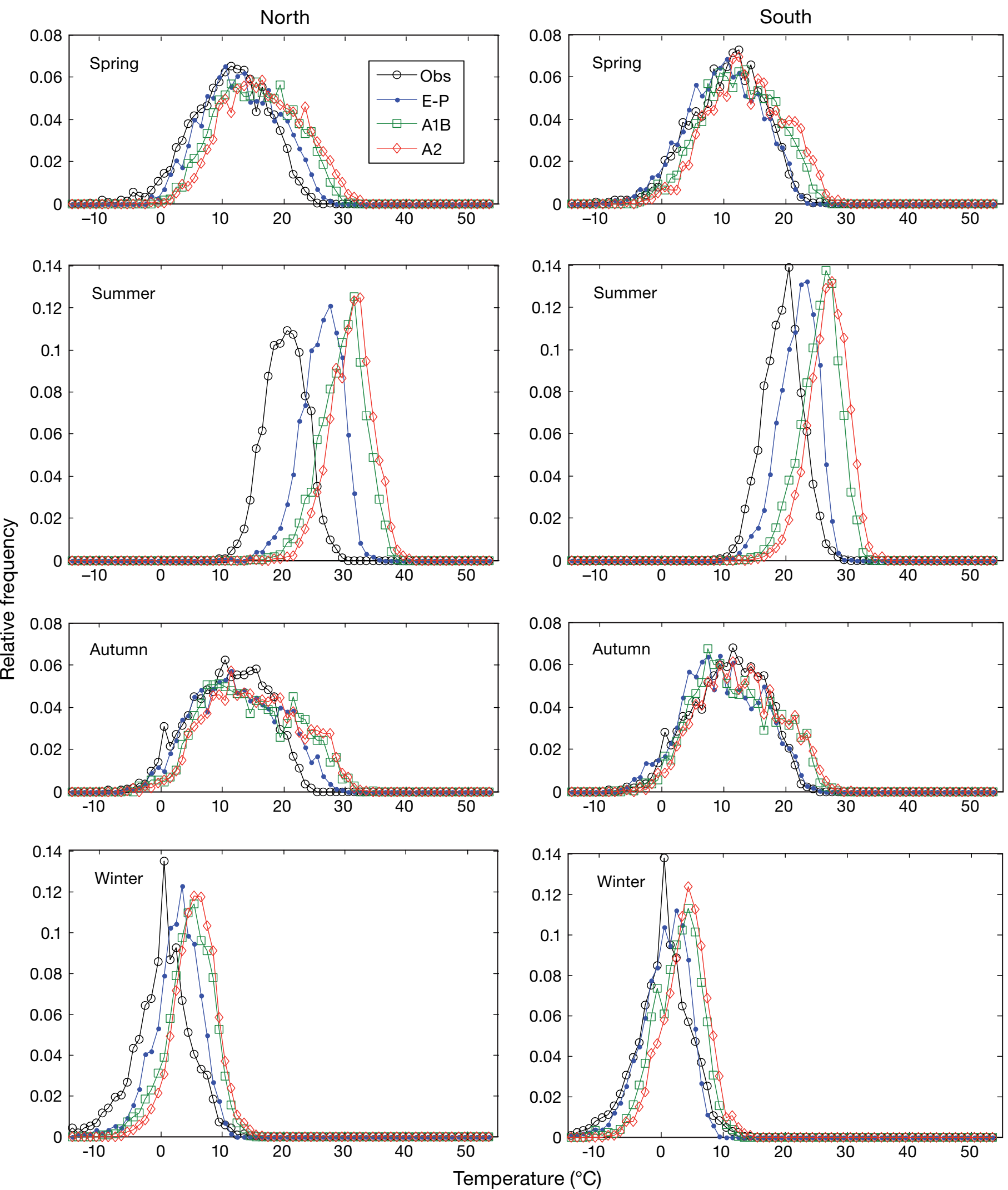

Fig. 2. Seasonal relative frequencies of temperature for North and South Serbia from observations (Obs), the EBU-POM (E-P) simulations for the reference period 1961-1990, and the A1B and A2 scenarios 


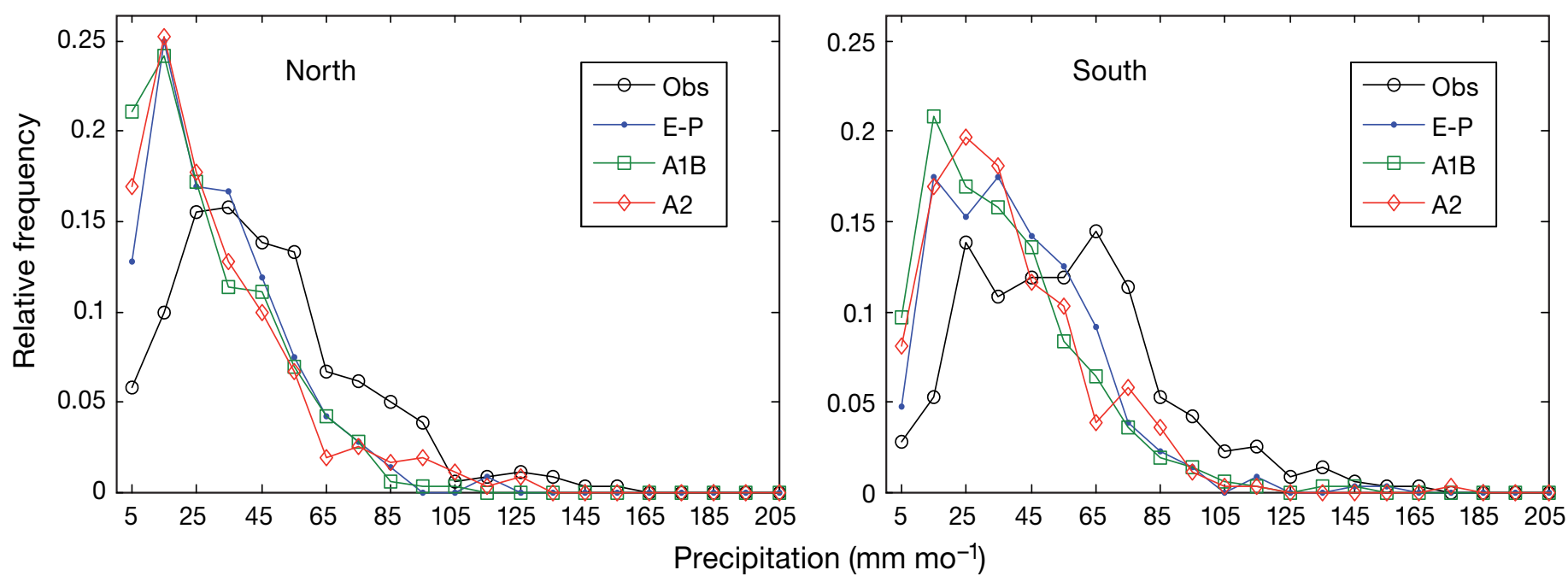

Fig. 3. Relative frequencies of monthly precipitation sums for North and South Serbia from observations (Obs), the EBU-POM (E-P) simulations for the reference period 1961-1990, and the A1B and A2 scenarios

quency of temperature (Fig. 2) into consideration, the model is 'warmer'. In many areas of the world the number of frost days has decreased (Alexander et al. 2006), but many places in the EM have shown significant increasing trends in the Fd index on an annual scale. The area around Serbia and Montenegro features significant positive trends on the order of $4-6 \mathrm{~d}$ decade $^{-1}$ (Kostopoulou \& Jones 2005). According to the observations, we found a positive trend of Fd during autumn (significant for SS), while trends were negative in the other seasons.

There is a substantial underestimation of consecutive frost days (CFD) in both areas in winter. The model is robust in presenting CFD for spring and autumn in SS (Table 5). Error in the winter comes from the higher minimal temperature in the model. There is a significant negative trend in the observations during spring for all of Serbia.

Precipitation incidences $\geq 10 \mathrm{~mm}$ (R10) are underestimated in all seasons in both areas. The largest discrepancy between simulated and observed values is during the summer in NS.

Similar to R10, the simulated simple daily intensity index (SDII) shows less rain on wet days. The largest difference in SDII between the model and observations is during the summer period in NS and during the autumn in SS. We found negative trends of observed SDII and R10 values during winter in both areas. Similarly, Kostopoulou \& Jones (2005) pointed out that negative trends in R10 and SDII dominate the easternmost part of the Mediterranean and Balkans, indicating tendencies towards an increasingly dry climate over the second half of the 20th century.
The model is fairly accurate in simulating the number of consecutive dry days (CDD). There is an overestimation during the summer in NS, which is in agreement with the previously mentioned behaviors of R10, SDII, and Td indices. The regional model results for spring and autumn in SS are in good agreement with observations, while for the winter and summer, slight overestimation occurs. The season with the longest dry periods is autumn. A tendency towards drier conditions exists during winter in observations and model simulations. Kostopoulou \& Jones (2005) also found that the calculated CDD annual index reflects increases in CDD for the eastern and southern Mediterranean.

The growing season length (GSL) is very well simulated (Table 6). Better agreement is achieved for SS than for NS. The difference between modeled and observed data at the beginning of the growing season is $<3 \%$ in SS and at the end is $<0.1 \%$ in NS. The model calculates an earlier end of the GSL in SS.

\subsubsection{Future period (2071-2100)}

Differences in the values of indices between the present (1961-1990) and future climate (2071-2100) according to the 2 scenarios (Tables $5 \& 6$ ) are:

- Td: There is an increase in both areas and in all seasons. Note that the greatest overestimation ( 125\%) in the reference period is during summer. According to the A2 scenario, warming is more intense during spring in both areas. Also, significant positive trends are found for all seasons, except for spring in SS. 
Table 5. Seasonal averages of the indices (definitions given in Table 1) for observations (Obs), EBU-POM (E-P) for the reference period and for the A1B and A2 scenarios (first 4 columns). Seasonal differences of the indices between EBU-POM and observations for the 1961-1990 period, and between the future period (2071-2100) and reference period (1961-1990) according, respectively, to the A1B and A2 scenarios. Statistically significant trends (of corresponding time series) at $5 \%$ are given in bold and marked with plus or minus sign to indicate a positive or negative trend, respectively; - no data

\begin{tabular}{|c|c|c|c|c|c|c|c|c|c|}
\hline & \multirow[t]{2}{*}{ Season } & \multirow[t]{2}{*}{ Index } & \multicolumn{2}{|c|}{$1961-1990$} & \multicolumn{2}{|c|}{$2071-2100$} & \multicolumn{3}{|c|}{ - Seasonal differences } \\
\hline & & & Obs & E-P & $\mathrm{A} 1 \mathrm{~B}$ & A2 & E-P - Obs & $\mathrm{A} 1 \mathrm{~B}-\mathrm{E}-\mathrm{P}$ & A2 - E-P \\
\hline \multirow[t]{24}{*}{ North } & \multirow[t]{6}{*}{ MAM } & $\mathrm{Td}$ & $0.69^{-}$ & 1.76 & 7.08 & $11.35^{+}$ & 1.07 & 5.32 & 9.59 \\
\hline & & $\mathrm{Fd}$ & 12.50 & 3.26 & $0.65^{-}$ & $0.42^{-}$ & -9.24 & -2.61 & -2.84 \\
\hline & & CFD & $5.91^{-}$ & 2.45 & $0.55^{-}$ & $0.39^{-}$ & -3.45 & -1.90 & -2.06 \\
\hline & & $\mathrm{CDD}$ & 15.82 & 19.79 & 22.08 & $24.27^{+}$ & 3.97 & 2.29 & 4.48 \\
\hline & & SDII & 5.95 & 4.52 & $4.94^{+}$ & 5.18 & -1.43 & 0.42 & 0.65 \\
\hline & & R10 & 3.56 & 1.62 & 1.96 & 1.94 & -1.94 & 0.35 & 0.33 \\
\hline & \multirow[t]{6}{*}{ JJA } & $\mathrm{Td}$ & 18.66 & 60.81 & 79.18 & $84.31^{+}$ & 42.15 & 18.37 & 23.50 \\
\hline & & $\mathrm{Fd}$ & - & - & - & - & - & - & - \\
\hline & & CFD & - & - & - & - & - & - & - \\
\hline & & CDD & 16.91 & 23.78 & 28.15 & 27.63 & 6.87 & 4.37 & 3.85 \\
\hline & & SDII & 8.55 & $4.62^{+}$ & 4.84 & 5.09 & -3.93 & 0.22 & 0.47 \\
\hline & & R10 & 6.03 & 1.01 & 0.89 & 1.03 & -5.02 & -0.12 & 0.02 \\
\hline & \multirow[t]{6}{*}{$\mathrm{SON}$} & $\mathrm{Td}$ & 1.78 & 5.66 & 12.64 & $14.16^{+}$ & 3.87 & 6.98 & 8.5 \\
\hline & & $\mathrm{Fd}$ & 12.30 & 5.89 & 3.19 & 2.61 & -6.41 & -2.70 & -3.28 \\
\hline & & CFD & 5.99 & 3.90 & 2.79 & 2.21 & -2.10 & -1.10 & -1.68 \\
\hline & & $\mathrm{CDD}$ & 25.11 & 26.17 & 29.36 & 29.95 & 1.06 & 3.19 & 3.78 \\
\hline & & SDII & 6.64 & 4.67 & 4.93 & 5.53 & -1.97 & 0.26 & 0.86 \\
\hline & & R10 & 3.42 & 1.45 & 1.36 & 1.84 & -1.98 & -0.09 & 0.39 \\
\hline & \multirow[t]{6}{*}{ DJF } & $\mathrm{Td}$ & - & - & - & - & - & - & - \\
\hline & & $\mathrm{Fd}$ & 61.46 & 31.29 & 17.68 & 11.04 & -30.16 & -13.62 & -20.25 \\
\hline & & CFD & 24.62 & 6.95 & 5.40 & $3.98^{+}$ & -17.67 & -1.55 & -2.96 \\
\hline & & CDD & 17.57 & 20.50 & 20.45 & 20.71 & 2.94 & -0.05 & 0.21 \\
\hline & & SDII & 5.22 & 4.45 & 4.69 & $5.31^{+}$ & -0.76 & 0.23 & 0.86 \\
\hline & & R10 & 2.60 & $2.16^{+}$ & 2.21 & $3.53^{+}$ & -0.44 & 0.05 & 1.37 \\
\hline \multirow[t]{24}{*}{ South } & \multirow[t]{6}{*}{ MAM } & $\mathrm{Td}$ & 0.78 & $0.15^{-}$ & 2.21 & 4.72 & -0.63 & 2.05 & 4.57 \\
\hline & & $\mathrm{Fd}$ & 15.19 & 11.24 & 5.11 & $3.38^{-}$ & -3.96 & -6.12 & -7.86 \\
\hline & & CFD & $6.62^{-}$ & 6.29 & 3.02 & $2.18^{-}$ & -0.33 & -3.27 & -4.10 \\
\hline & & CDD & 15.72 & 16.30 & 19.31 & 21.53 & 0.58 & 3.01 & 5.23 \\
\hline & & SDII & 6.94 & 5.60 & 5.68 & 5.87 & -1.34 & 0.08 & 0.27 \\
\hline & & R10 & 5.63 & 3.58 & 3.31 & 3.17 & -2.05 & -0.27 & -0.41 \\
\hline & \multirow[t]{6}{*}{ JJA } & $\mathrm{Td}$ & 20.07 & 26.02 & 55.8 & $64.82^{+}$ & 5.96 & 29.78 & 38.8 \\
\hline & & $\mathrm{Fd}$ & - & - & - & - & - & - & - \\
\hline & & CFD & - & - & - & - & - & - & - \\
\hline & & $\mathrm{CDD}$ & 16.22 & 20.01 & 23.33 & 20.56 & 3.79 & 3.32 & 0.55 \\
\hline & & SDII & 8.48 & 5.98 & 6.18 & 6.18 & -2.51 & 0.20 & 0.20 \\
\hline & & R10 & 6.45 & 3.27 & 2.85 & 3.14 & -3.18 & -0.42 & -0.14 \\
\hline & \multirow[t]{6}{*}{ SON } & $\mathrm{Td}$ & 2.61 & 1.17 & 4.66 & $4.85^{+}$ & -1.44 & 3.49 & 3.68 \\
\hline & & $\mathrm{Fd}$ & $13.92^{+}$ & 10.68 & 5.9 & 4.62 & -3.24 & -4.78 & -6.06 \\
\hline & & CFD & 6.15 & 5.97 & 3.48 & 3.08 & -0.19 & -2.48 & -2.89 \\
\hline & & CDD & 21.96 & 23.47 & 26.76 & 29.32 & 1.51 & 3.29 & 5.85 \\
\hline & & SDII & 7.76 & 5.06 & 5.33 & 5.7 & -2.7 & 0.28 & 0.65 \\
\hline & & R10 & 5.13 & 1.99 & 1.83 & 1.83 & -3.14 & -0.16 & -0.16 \\
\hline & \multirow[t]{6}{*}{ DJF } & $\mathrm{Td}$ & - & - & - & - & - & - & - \\
\hline & & $\mathrm{Fd}$ & 63.84 & 53.54 & 36.74 & 27.86 & -10.3 & -16.8 & -25.67 \\
\hline & & CFD & 23.80 & 10.51 & 7.58 & 6.21 & -13.29 & -2.93 & -4.30 \\
\hline & & CDD & $16.47^{+}$ & 19.87 & $20.86^{+}$ & 21.54 & 3.39 & 1.00 & 1.68 \\
\hline & & SDII & 5.71 & 4.52 & 4.70 & $5.07^{+}$ & -1.19 & 0.18 & 0.55 \\
\hline & & R10 & 3.86 & $2.06^{+}$ & 2.02 & $2.55^{+}$ & -1.80 & -0.03 & 0.49 \\
\hline
\end{tabular}


Table 6. Averages of the beginning, end and length (GSL) of growing season for observations (Obs), the EBU-POM (E-P) for the reference period, and for the A1B and A2 scenarios (first 4 columns). Differences of these variables between the EBU-POM and observations for the period 1961-1990, and between the future (2071-2100) and reference period (1961-1990) for the A1B and A2 scenarios for North and South Serbia

\begin{tabular}{|c|c|c|c|c|c|c|c|c|}
\hline & \multirow[t]{2}{*}{ Index } & \multicolumn{2}{|c|}{ 1961-1990 } & \multicolumn{2}{|c|}{ 2071-2100 } & \multicolumn{3}{|c|}{$\longrightarrow$ Differences- } \\
\hline & & Obs & E-P & $\mathrm{A} 1 \mathrm{~B}$ & A2 & E-P - Obs & A1B - E-P & $\mathrm{A} 2$ - E-P \\
\hline \multirow[t]{3}{*}{ North } & Begin & 71.64 & 49.47 & 23.87 & 21.03 & -22.18 & -25.60 & -28.43 \\
\hline & End & 323.88 & 323.70 & 334.17 & 339.67 & -0.18 & 10.47 & 15.97 \\
\hline & GSL & 253.24 & 275.12 & 311.32 & 319.58 & 21.88 & 36.20 & 44.45 \\
\hline \multirow[t]{3}{*}{ South } & Begin & 72.29 & 71.20 & 45.43 & 39.63 & -1.09 & -25.77 & -31.57 \\
\hline & End & 326.62 & 314.70 & 328.07 & 332.43 & -11.92 & 13.37 & 17.73 \\
\hline & GSL & 255.32 & 244.64 & 283.53 & 293.93 & -10.68 & 38.89 & 49.29 \\
\hline
\end{tabular}

- Fd and CFD: Smaller numbers are expected for all seasons in both scenarios. For both parameters, the decrease is $>60 \%$ in NS during spring for the A1B scenario, as well as in both areas during spring according to the A2 scenario. SS has more frost days than NS, as in the reference period. Trends are negative and significant for spring, except for SS for the A1B scenario. Positive trends are expected during autumn for both scenarios.

- R10: There is an increase during spring and winter in the north. In the other seasons and in the south for the A1B scenario, there is a small decrease, $<15 \%$. For the A2 scenario, an increase is expected during winter (about $20 \%$ ) in SS and for all seasons in NS.

- SDII: In all seasons and for both areas of Serbia, there is a small increase in SDII. The increase is slightly larger according to the A2 than to the A1B scenario. As with R10, a positive trend is expected for all seasons according to the A2 scenario (significant in winter). For the SE Mediterranean, Oikonomou et al. (2008) found a decrease in rainfall intensity in winter, spring, and summer, but an increase in autumn.

- CDD: The duration of the dry period is expected to be extended under both scenarios and for all seasons. The greatest increase is expected in spring and according to the A2 scenario. It is interesting that in summer longer dry periods are predicted for the A1B than for the A2 scenario. Future climate time series (not shown) indicate an increase for autumn and winter of the length of dry periods in the last third of the 2071-2100 period. For both scenarios and all of Serbia a negative tendency during summer and a positive one in autumn and winter are expected. Oikonomou et al. (2008) demonstrated a general trend towards longer dry spells in the future. The maximum increase of dry spell length is expected in winter and spring for the southern part of the EM.
- GSL: The parameters presented in Table 6 show that the vegetation period will start earlier and end later, i.e. the GSL will lengthen. This has already been observed since the end of the 20th century in the Northern Hemisphere (Frich et al. 2002). According to the A2 scenario, the length of the growing season will be greater than in the A1B scenario. The same trend is obtained, using a coupled global climate model with 5 different scenarios, for the last $20 \mathrm{yr}$ of the 21st century for northern Europe (Meehl et al. 2004).

\section{DISCUSSION AND CONCLUSIONS}

We analyzed potential changes in the frequency of extreme weather events in the future. These were calculated for the region of Serbia, from observations and simulations obtained by the coupled regional EBU-POM Model. Overall, simulation for the reference period reproduces the climate patterns observed, although with some biases. The regional model shows a tendency to overestimate temperature in summer and underestimate precipitation. These biases, on an annual basis of $0.64^{\circ} \mathrm{C}$ for temperature and $-0.67 \mathrm{~mm}$ $\mathrm{d}^{-1}$ for precipitation, are similar to those determined by Giorgi et al. (2004b) and Jacob et al. (2008). The largest bias, i.e. excessive warming, is found during summer in NS. This represents a quite common problem for climate models in the region of Pannonia known as the 'summer drying problem' (Hagemann et al. 2004, Jacob et al. 2008). The EBU-POM underestimates the interannual temperature variability (except in summer). The interannual variability of precipitation does not show pronounced seasonal variations. Despite these biases, the simulated climate is generally in good agreement with that observed.

As for climate indices for the reference period, we found that the model overestimates the total number 
of tropical days (Td) and underestimates the number of frost days ( $\mathrm{Fd})$, with a positive trend in Fd during autumn and negative one in the other seasons. The south of Serbia is colder than the north (fewer Td and more Td), which is consistent with the observed data. In Karl et al. (1999), the number of frost days has decreased in many areas of the world, but Kostopoulou \& Jones (2005) showed a significantly increasing trend in the EM for Fd on an annual scale.

The present climate has beem characterized by an increase in heavy precipitation events (Groisman et al. 1999, Frich et al. 2002), but for the EM region, Kostopoulou \& Jones (2005) found generally negative trends. These trends, in addition to the strongly positive trends in the maximum number of consecutive dry days (CDD), indicate a tendency towards a drier climate over time. Similarly, we found negative trends in SDII and R10 and a tendency towards drier conditions during winter in both parts of Serbia. A comparison in trends over the entire area of Serbia between observations and the model shows that the model simulates the seasonal pattern.

Generally, trends according to the A2 scenario indicate, for both regions, an overall increase in surface air temperature and a decrease in precipitation by the end of the 21st century. Önol \& Semazzi (2009) predicted a temperature increase of about $7^{\circ} \mathrm{C}$ in summer and $<3^{\circ} \mathrm{C}$ in winter in the Balkan countries. Also, Gao \& Giorgi (2008) have shown a warming trend during summer over the Balkans and a decrease in winter precipitation over most of the EM. Somot et al. (2008) showed warming for all seasons, with maximum values (higher than $+6^{\circ} \mathrm{C}$ ) in the eastern part of Europe in winter and in the southern part of Europe in summer. A drying trend was simulated over Europe and the Mediterranean basin. According to the results of Bartholy et al. (2008), using the PRUDENCE results, the greatest warming $\left(4.8^{\circ} \mathrm{C}\right)$ is expected in summer over the Carpathian Basin (including the northern part of Serbia). In our simulations, surface temperature will increase by $4.8^{\circ} \mathrm{C}$ in the summer, while seasonal precipitation sums will decrease to $6 \mathrm{~mm}$ in spring and will increase up to $13 \mathrm{~mm}$ in winter. Temperature variability will generally increase for all seasons, while the interannual variability of precipitation will be most pronounced in autumn.

We predict an increase in the number of tropical days and, at the same time, a decrease in the total number of frost days. The increase in Td in the north is greater than that in the south, while the opposite trend is expected for Fd. We expect shorter durations of frost and longer durations of vegetation periods.
Increase or decrease in the number of heavy rain days depends on the season and scenario; however, both scenarios agree that heavy rain days will increase during spring in NS. According to the A2 scenario, dry periods will be longer and the number of days with heavy rain will increase during winter in both regions. Chauvin \& Denvil (2007) found longer dry events in summer over Europe and the Mediterranean, while our results show longer dry periods for all seasons. Similarly, the analysis of Oikonomou et al. (2008) demonstrated longer dry spells for all seasons, except in autumn, for which the opposite trend is predicted for the EM.

For all indices considered, the changes expected according to the A1B scenario are smaller than those expected according to the A2 scenario.

With the help of dynamic downscaling we detected significant climate variation for a very small region which is poorly resolved in a global model run. All chosen indices indicate that climate changes will have serious implications on vegetable and fruit growing, both dominant crops in Serbian agriculture. Also, changes in precipitation indices are good indicators regarding the availability of water resources in the future.

Analysis using climate indices may offer important insights for the development of strategies to address SE Europe's climate change problem. However, further investigation is needed to reduce the uncertainties in regional climate modeling (Giorgi et al. 2009). Probably, the most vital uncertainties are related to AOGCM configuration, capture of the internal climate variability, region of interest, relevance of emission/concentration scenarios, and, finally, the regional model used for downscaling. The most frequent suggestion to overcome these uncertainties is to introduce an ensemble approach, which would allow us to present information on climatic variables in the form of probability density functions.

Acknowledgements. The present study was partially supported by the Serbian Ministry of Science under Grants No. III43007 and 176013 and the Italian Ministry for the Environment, Land and Sea through project SINTA. The authors highly appreciated the reviewers' comments and suggestions, which led to considerable improvement of the paper.

\section{LITERATURE CITED}

Alexander LV, Zhang X, Peterson TC, Caesar J and others (2006) Global observed changes in daily climate extremes of temperature and precipitation. J Geophys Res 111:D05109. doi:10.1029/2005JD006290

Arakawa A, Lamb V (1977) Computational design of the 
basic dynamical processes of the UCLA general circulation model. Methods Comput Phys 17:174-265

Artale V, Calmanti S, Carillo A, Dell'Aquila A and others (2010) An atmosphere-ocean regional climate model for the Mediterranean area: assessment of a present climate simulation. Clim Dyn 35:721-740. doi:10.1007/s00382009-0691-8

> Bartholy J, Pongrácz R (2007) Regional analysis of extreme temperature and precipitation indices for the Carpathian basin from 1946 to 2001. Global Planet Change 57:83-95

Bartholy J, Pongrácz R, Gelyló G, Szabó P (2008) Analysis of expected climate change in the Carpathian basin using the PRUDENCE results. Időjárás 112:249-264

Blumberg A, Mellor G (1987) Description of a threedimensional coastal ocean circulation model. In: Heaps N (ed) Three-dimensional coastal ocean models, vol 4. American Geophysical Union, Washington, DC

> Brasseur P, Brankart JM, Shomnenauen R, Beckers JM (1996) Seasonal temperature and salinity fields in the Mediterranean Sea: climatological analyses of a historical data set. Deep Sea Res I 43:159-192

> Chauvin F, Denvil S (2007) Changes in severe indices as simulated by two French coupled global climate models. Global Planet Change 57:96-117

> Dettinger MD, Cayan DR, Meyer MK, Jeton AE (2004) Simulated hydrologic responses to climate variations and change in the Merced, Carson, and American River basins, Sierra Nevada, California, 1900-2099. Clim Change 62:283-317

Djurdjevic V, Rajkovic B (2008) Verification of a coupled atmosphere-ocean model using satellite observations over the Adriatic Sea. Ann Geophys 26:1935-1954

Djurdjevic V, Rajkovic B (2011) Development of the EBUPOM coupled regional climate model and results from climate change experiments. In: Mihailovic DT, Lalic B (eds) Advances in environmental modeling and measurements. Nova Science, NY, p 23-32

$>$ Drakopoulos P, Lascaratos A (1999) Modelling the Mediterranean Sea: climatological forcing. J Mar Syst 20: $157-173$

> Fels SB, Schwarzkopf MD (1975) The simplified exchange approximation: a new method for radiative transfer calculations. J Atmos Sci 32:1475-1488

Fennessy MJ, Shukla J (2000) Seasonal prediction over North America with a regional model nested in a global model. J Clim 13:2605-2627

Fichefet T, Morales Maqueda MA (1997) Sensitivity of global sea ice model to the treatment of ice thermodynamics and dynamics. J Geophys Res 102:12609-12646

Frich P, Alexander LV, Della-Marta P, Gleason B, Haylock M, Klein Tank AMG, Peterson T (2002) Observed coherent changes in climatic extremes during the second half of the twentieth century. Clim Res 19:193-212

Gao X, Giorgi F (2008) Increased aridity in the Mediterranean region under greenhouse gas forcing estimated from high resolution simulations with a regional climate model. Global Planet Change 62:195-209

Giorgi F (2006) Regional climate modeling: status and perspectives. J Phys IV 139:101-118

> Giorgi F, Mearns LO (1999) Introduction to special section: regional climate modeling revisited. J Geophys Res 104: 6335-6352

Giorgi F, Bi X, Pal JS (2004a) Mean, interannual variability and trends in a regional climate change experiment over Europe. I. Present day climate (1961-1990). Clim Dyn 22:
$733-756$

> Giorgi F, Bi X, Pal JS (2004b) Mean, interannual variability and trends in a regional climate change experiment over Europe. II. Climate change scenarios (2071-2100). Clim Dyn 23:839-858

Giorgi F, Jones C, Asrar GR (2009) Addressing climate information needs at regional level: the CORDEX framework. WMO Bull 58:175-183

Goubanova K, Li L (2007) Extremes in temperature and precipitation around the Mediterranean basin in an ensemble of future climate scenario simulations. Global Planet Change 57:27-42

> Groisman PY, Karl TR, Easterling DR, Knight RW and others (1999) Changes in the probability of heavy precipitation: important indicators of climatic change. Clim Change 42: $243-283$

Gualdi S, Navarra A, Guilyardi E, Delecluse P (2003a) Assessment of the tropical Indo-Pacific climate in the SINTEX CGCM. Ann Geophys 46:1-26

Gualdi S, Guilyardi E, Navarra A, Masina S (2003b) The interannual variability in the tropical Indian Ocean as simulated by a CGCM. Clim Dyn 20:567-582

Gualdi S, Rajkovic B, Djurdjevic V, Castellari S, Scoccimarro E, Navarra A, Dacic M (2008) Simulations of climate change in the Mediterranean area. Final scientific report. Available at: www.earth-prints.org/handle/2122/ 4675 (accessed on Sep 8, 2011)

> Guilyardi E, Delecluse P, Gualdi S, Navarra A (2003) Mechanisms for ENSO phase change in a coupled GCM. J Clim 16:1141-1158

Hagemann S, Machenhauer B, Jones R, Christensen OB, Deque M, Jacob D, Vidale PL (2004) Evaluation of water and energy budgets in regional climate models applied over Europe. Clim Dyn 23:547-567

IPCC (Intergovernmental Panel on Climate Change) (2007) The physical science basis. In: Solomon S, Qin D, Manning M, Chen Z, Marquis M, Averyt KB, Tignor M, Miller HL (eds) Contribution of Working Group I to the 4th assessment report of the IPCC. Cambridge University Press, Cambridge

Jacob D, Barring L, Christensen OB, Christensen JH and others (2007) An inter-comparison of regional climate models for Europe: model performance in present-day climate. Clim Change 81:31-52

Jacob D, Kotova L, Lorenz P, Moseley Ch, Pfeifer S (2008) Regional climate modeling activities in relation to the CLAVIER project. Időjárás 112:141-153

> Janjic ZI (1990) Physical package for step-mountain, Eta coordinate model. Mon Weather Rev 118:1429-1443

Janjic ZI (1996) The surface layer parameterization in NCEP Eta model. CAS/C WGNE 4.16-4.17, WMO, Geneva

Jones PD, Parker DE, Osborn TJ, Briffa KR (2006) A compendium of data on global change. Carbon Dioxide Information Analysis Center, Oak Ridge National Laboratory, US Department of Energy, Oak Ridge, TN

Kalnay E, Kanamitsu M, Kistler R, Collins W and others (1996) The NCEP/NCAR reanalysis project. Bull Am Meteorol Soc 77:437-471

Karl TR, Knight RW, Easterling DR, Quayle RG (1996) Indices of climate change for the United States. Bull Am Meteorol Soc 77:279-291

Karl TR, Nicholls N, Ghazi A (1999) CLIVAR/GCOS/WMO Workshop on indices and indicators for climate extremes. Clim Change 42:3-7

- Klein Tank AMG, Können GP (2003) Trends indices of daily 
temperature and precipitation extremes in Europe, 1946-99. J Clim 16:3665-3680

Kostopoulou E, Jones PD (2005) Assessment of climate extremes in the eastern Mediterranean. Meteorol Atmos Phys 89:69-85

Madec G, Delecluse P, Imbard M, Levy C (1998) OPA 8.1 Ocean General Circulation Model reference manual. Internal Rep. 11, Inst. Pierre-Simon Laplace, Paris

Meehl GA, Tebaldi C, Nychka D (2004) Changes in frost days in simulations of twenty-first century climate. Clim Dyn 23:495-511

Mellor GL (2002) Program in atmospheric and oceanic sciences. Princeton University, Princeton, NJ

Mesinger F, Janjic ZI, Nickovic S, Gavrilov D, Daven D (1988) The step mountain coordinate: model description and performance for cases of alpine lee cyclogenesis and for a case of an Appalachian redevelopment. Mon Weather Rev 116:1493-1518

Moberg A, Jones P, Lister D, Walther A, Brunet A (2006) Indices for daily temperature and precipitation extremes in Europe analyzed for the period 1901-2000. J Geophys Res 111:D22106. doi:10.1029/2006JD007103

Nakicenovic N, Swart R (2000) Special report of the Intergovernmental Panel on Climate Change. Cambridge University Press, Cambridge

Nastos PT, Matzarakis AP (2008) Variability of tropical days over Greece within the second half of the twentieth century. Theor Appl Meteorol 93:75-89

Oikonomou C, Flocas HA, Hatzaki M, Asimakopoulos DN, Giannakopoulos C (2008) Future changes in the occurrence of extreme precipitation events in eastern Mediterranean. Global NEST J 10:255-262

Önol B, Semazzi F (2009) Regionalization of climate change simulations over the eastern Mediterranean. J Clim 22: 1944-1961

Editorial responsibility: Filippo Giorgi, Trieste, Italy
Pérez C, Nickovic S, Pejanovic G, Baldasano JM, Özsoy E (2006) Interactive dust-radiation modeling: a step to improve weather forecasts. J Geophys Res 111:D16206. doi:10.1029/2005JD006717

Peterson T, Folland C, Gruza G, Hogg W, Mokssit A, Plummer N (2001) Report on the activities of the working group on climate change detection and related rapporteurs. WCDMP-No.47, WMO-TD No. 1071, WMO, Geneva

Roeckner E, Arpe K, Bengtsson L, Christoph M and others (1996) The atmospheric general circulation model ECHAM-4: model description and simulation of presentday climate. Report 218, Max-Planck-Institute, Hamburg

Somot S, Sevault F, Déqué M, Crépon M (2008) 21st century climate change scenario for the Mediterranean using a coupled atmosphere-ocean regional climate model. Global Planet Change 63:112-126

> Tebaldi C, Hayhoe K, Arblaster JM, Meehl GA (2006) Going to the extremes an intercomparison of model-simulated historical and future changes in extreme events. Clim Change 79:185-211

> Unkasevic M, Vujovic D, Tosic I (2005) Trends in extreme summer temperatures at Belgrade. Theor Appl Climatol 82:199-205

Winninghoff FJ (1968) On the adjustment toward a geostrophic balance in a simple primitive equation model with application to the problems of initialization and objective analysis. PhD dissertation, University of California, Los Angeles

Xue Y, Vasic R, Janjic Z, Mesinger F, Mitchell KE (2007) Assessment of dynamic downscaling of the continental U.S. regional climate using the Eta/SSiB Regional Climate Model. J Clim 20:4172-4193

Zavatarielli M, Mellor GL (1995) A numerical study of the Mediterranean Sea circulation. J Phys Oceanogr 25:1384-1414

Submitted: July 7, 2010; Accepted: April 20, 2011

Proofs received from author(s): September 8, 2011 